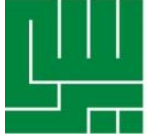

KATA KUNCI

KEYWORDS

ABSTRAK

ABSTRACT

\section{Asertivitas dan Penyesuaian Perkawinan pada Dewasa Awal di Aceh Tengah}

\section{Assertiveness and Marital Adjustment of Young Adult in Central Aceh}

\author{
Gemilang Silemi Retiara ${ }^{1}$, Maya Khairani ${ }^{2}$, Nucke Yulandari ${ }^{3}$ \\ Program Studi Psikologi Fakultas Kedokteran Universitas Syiah Kuala \\ Jl. Teuku Nyak Arief Darussalam Banda Aceh. Aceh 23111 \\ Email: bungeniate@yahoo.co.id; khairani.maya@unsyiah.ac.id
}

asertivitas, penyesuaian perkawinan, dewasa awal

assertiveness, marital adjustment, early adulthood

Penyesuaian perkawinan merupakan proses membiasakan diri (adaptasi) dengan situasi baru sebagai suami istri dalam membentuk keluarga untuk memenuhi harapan dan tujuan perkawinan, serta menyelesaikan masalah yang muncul dalam perkawinan. Salah satu faktor penting yang dapat memengaruhi penyesuaian perkawinan adalah berkomunikasi secara asertif. Ciri individu yang memiliki asertivitas adalah mampu menyatakan perasaan, keinginan, dan hak-haknya secara terbuka. Individu yang mampu berperilaku asertif akan mudah dalam menyesuaikan diri terutama dalam perkawinan. Penelitian ini bertujuan untuk mengetahui hubungan antara asertivitas dengan penyesuaian perkawinan pada dewasa awal di Aceh Tengah. Teknik pengambilan sampel pada penelitian ini adalah menggunakan teknik acak sederhana. Sampel penelitian adalah dewasa awal dengan kriteria usia 20 tahun hingga 39 tahun, usia pernikahan 4 bulan hingga 2 tahun, dan berdomisili di Aceh Tengah. Pengumpulan data dilakukan dengan mengunakan skala asertivitas sebanyak 16 pernyataan dan skala penyesuaian perkawinan sebanyak 20 pernyataan. Hasil analisis data menggunakan teknik korelasi pearson menunjukkan koefisien korelasi ( $r$ ) sebesar 0,649 dengan nilai $p=0,000(p<0,01)$. Hal ini dapat diartikan bahwa terdapat hubungan positif antara asertivitas dengan penyesuaian perkawinan. Artinya semakin tinggi asertivitas maka semakin baik penyesuaian perkawinan atau sebaliknya.

Marital adjustment is an adaptation process to new situations as husband and wife as a family to reach the expectation and purpose of marriage and to solve problems that arise in marriage life. One important factor that can influence marital adjustment is assertive communication. In addition, individuals who have assertiveness are able to express feelings, desires, and rights openly. Individuals who are able to behave with assertive would be easy to adapt, especially in marriage. The aim of this study was to determine the relationship between assertiveness and marital adjustment on early adulthood in Central Aceh using simple random technique. The sample of the study was early adulthoods from 20 to 39 years old that already in 4 months up to 2 years marriage age, and stays in Central Aceh. Data was collected using assertiveness scale (16 items) and marital adjustment scale (20 items). The analysis result of the 
data using the Pearson product moment correlation technique showed the correlation coefficients $(r) 0.649$ with $p=0.000(p<0.01$ ). That implied there was a positive relationship between assertiveness and marital adjustment. The higher assertiveness the better marital adjustment or vise versa.

\section{PENDAHULUAN}

Masa dewasa awal merupakan masa peralihan baik fisik, intelektual maupun sosial dari remaja menuju dewasa akhir. Pada masa dewasa awal individu memiliki tugas perkembangan secara psikososial yaitu mencari dan menemukan calon pasangan hidup, menikah dan membina kehidupan rumah tangga (Havighurst dalam Dariyo, 2004). Peran baru yang dijalankan oleh individu dewasa awal salah satunya adalah peran sebagai suami dan istri yang terjadi dalam ikatan perkawinan. Perkawinan merupakan ikatan lahir batin dan persatuan antara dua pribadi yang berasal dari keluarga, sifat, kebiasaan dan budaya yang berbeda (Anjani \& Suryanto, 2006).

Duvall (1977) mengatakan ada beberapa alasan individu dewasa awal memutuskan untuk menikah salah satunya untuk meraih kebahagiaan. Atwater dan Duffy (2009) mengatakan bahwa kebahagiaan perkawinan tergantung pada apa yang terjadi saat pasangan memasuki kehidupan perkawinan yaitu seberapa baik mereka mengalami kesesuaian atau kecocokan. Hal yang paling penting untuk meraih kebahagiaan adalah penyesuaian perkawinan. Penyesuaian perkawinan dilakukan pasangan suami istri sepanjang usia perkawinan. Sebuah perkawinan memerlukan penyesuaian terus menerus karena perbedaan yang ada pada pasangan menjadikan adanya hambatan dalam menjalani kehidupan perkawinan, bahkan memungkinkan terjadinya konflik dalam perkawinan (Locke dalam Duvall, 1977).

Landis (dalam Duvall, 1977) menyatakan bahwa permulaan konflik dan masalah-masalah penyesuaian terjadi pada empat bulan pertama perkawinan. Pentingnya penyesuaian sebagai suami atau istri dalam perkawinan akan berdampak pada keberhasilan hidup berumah tangga. Keberhasilan dalam hal ini mempunyai pengaruh yang kuat terhadap adanya kepuasan perkawinan, mencegah kekecewaan dan perasaan-perasaan bingung, sehingga memudahkan individu untuk menyesuaikan diri dalam kedudukannya sebagai suami istri (Hurlock, 2009).

Degenova dan Kay (2005) mengatakan bahwa dalam proses penyesuaian, masing-masing individu akan mengubah atau menyesuaikan pola perilakunya agar dapat terjalin suatu komunikasi dengan pasangannya untuk mencapai kepuasan yang maksimal dalam suatu hubungan perkawinan. Salah satu faktor penting yang dapat memengaruhi perkawinan adalah komunikasi. Hasil penelitian Prabowo (2006) menemukan komunikasi merupakan hal terpenting dalam menjalani perkawinan beda etnis dan faktor pendukung keberhasilan perkawinan tersebut adalah keterbukaan dalam berkomunikasi. Lee dan Ok (2002) juga melaporkan bahwa komunikasi yang terbuka antar pasangan berhubungan dengan kepuasan perkawinan. Penelitian dari Fizpatrick dan Ritchie (dalam Rini, 2009) juga menemukan bahwa pasangan yang berbahagia mengaku memiliki suatu komunikasi yang baik. Komunikasi yang baik mencakup keterbukaan diri tentang pikiran, dan perasaan kepada pasangan. Hal ini erat kaitannya dengan perilaku asertif atau asertivitas.

Menurut Rathus dan Nevid (1983) asertivitas adalah tingkah laku yang menampilkan keberanian untuk secara jujur dan terbuka menyatakan kebutuhan, perasaan dan pikiran-pikiran apa adanya, mempertahankan hak-hak pribadi, serta menolak permintaan-permintaan yang tidak masuk akal. Devito (2009) menyatakan 
perilaku asertif merupakan suatu bagian penting dalam hubungan interpersonal dan merupakan sikap yang diperlukan dalam komunikasi. Hasil penelitian Noller (1982) menemukan bahwa istri yang memiliki penyesuaian perkawinan yang buruk menginginkan suaminya untuk mengekspresikan emosinya dengan lebih jelas, memberi lebih banyak perhatian dan apresiasi pada istri, dan lebih banyak berkomunikasi. Temuan ini menekankan pentingnya komunikasi asertif untuk penyesuaian perkawinan.

Kertamuda (2009) yang mengatakan bahwa komunikasi yang terhambat menjadi salah satu alasan pasangan berpisah atau bercerai. Di Indonesia, jumlah kasus perceraian terus meningkat. Aceh sebagai salah satu Provinsi di Indonesia juga memperlihatkan jumlah kasus perceraian yang terus meningkat dari tahun ke tahun. Hal ini dapat dilihat dari data kasus perceraian di Aceh dari tahun 2009-2013 pada tabel 1.

Tabel 1. Jumlah Perceraian di Aceh Tahun 2009-2013

\begin{tabular}{cc}
\hline Tahun & Jumlah Perkara Perceraian \\
\hline 2009 & 2965 \\
2010 & 3440 \\
2011 & 3928 \\
2012 & 4009 \\
2013 & 4357 \\
\hline
\end{tabular}

Sumber: Mahkamah Syar'iyah Aceh (2013)

Pada tahun 2013, data perceraian dari 20 Kabupaten/Kota di Aceh yang terdata pada Mahkamah Syar'iah Aceh sejak Januari-Desember 2013 mencapai 4357 kasus. Dari kasus tersebut, Kabupaten Aceh Tengah (Takengon) menempati posisi kedua tertinggi pada kasus perceraian, yaitu mencapai 378 kasus. Ada banyak faktor yang menyebabkan besarnya jumlah angka kasus perceraian ini di Aceh. Hasil wawancara personal dengan salah satu pegawai bagian hukum kantor Mahkamah Syar'iah pada tanggal 6 September 2013 mengungkapkan faktor ketidakharmonisan menjadi faktor tertinggi yang mendasari kasus perceraian seperti ketidakmampuan beradaptasi dan kurangnya komunikasi atau tidak terbuka.

Berdasarkan uraian di atas dapat disimpulkan bahwa asertivitas sangat penting dan diperlukan dalam menjalani kehidupan perkawinan. Hal ini akan memudahkan timbulnya keterbukaan dalam menyampaikan keinginan serta perasaan dan harapan pasangannya sehingga dapat mengurangi masalah yang muncul dalam perkawinan, terutama saat melakukan penyesuaian perkawinan. Oleh karena itu maka peneliti tertarik untuk melakukan penelitian mengenai hubungan antara asertivitas dengan penyesuaian perkawinan pada dewasa awal di Aceh Tengah.

\section{METODE PENELITIAN}

Penelitian ini menggunakan metode kuantitatif. Pengambilan sampel dalam penelitian ini menggunakan simple random sampling dengan jumlah sampel sebanyak 90 responden di Aceh Tengah. Kriteria inklusi responden penelitian adalah Pria dan wanita dewasa awal usia 20-39 tahun telah menikah, usia perkawinan minimal 4 bulan sampai 2 tahun, belum memiliki anak, pernikahan monogami, sedangkan kriteria eksklusi usia dibawah 20 tahun, diatas 39 tahun, belum menikah, cerai (duda dan janda), poligami dan poliandri, sudah memiliki anak, usia perkawinan dibawah 4 bulan diatas 2 tahun.

\section{Metode Pengumpulan Data}

Metode yang digunakan dalam pengumpulan data adalah dengan menggunakan metode penskalaan model likert yang telah dimodifikasi, yaitu skala asertivitas terdiri dari 16 pernyataan dan skala penyesuaian perkawinan terdiri dari 20 pertanyaan yang disusun sendiri oleh peneliti. Pernyataan dalam skala bersifat favourable dan unfavourable dengan 4 alternatif jawaban yang terdiri dari sangat sesuai (SS), sesuai (S), tidak sesuai (TS), sangat tidak sesuai (STS). Pemberian skor untuk pernyataan favourable bergerak dari 4 hingga 1. Untuk skor pernyataan unfavourable bergerak dari 1 sampai 4. 


\section{Metode Analisa Data}

Analisis data yang digunakan untuk melihat hubungan antara asertivitas dengan penyesuaian perkawinan adalah dengan menggunakan program Statistical Package For Social Science (SPSS) versi 16, adapun teknik analisis data dalam penelitian ini adalah menggunakan korelasi Pearson product moment.

\section{ANALISIS DAN HASIL}

\section{Deskripsi Data Penelitian}

Gambaran umum mengenai data demografi subjek penelitian dapat dilihat pada tabel 2, dan data penelitian secara singkat dapat dilihat pada tabel 3. Data hipotetik pada tabel 3 dijadikan batasan dalam pengkategorian sampel penelitian yang terdiri dari tiga kategori yaitu tinggi, sedang, dan rendah. Kategorisasi ini didasari oleh asumsi bahwa skor sampel penelitian terdistribusi secara normal (Azwar, 2012). Adapun kategorisasi asertivitas dapat dilihat pada tabel 4 .

Berdasarkan tabel 4 dapat dilihat bahwa tidak ada sampel penelitian yang berada pada kategori rendah. Untuk kategorisasi penyesuaian perkawinan dapat dilihat pada tabel 4 .

\section{Uji Hipotesis}

Penelitian ini menguji hubungan antara dua variabel. Beberapa persyaratan untuk melakukan uji hipotesis hubungan adalah data kedua variabel terdistribusi secara normal serta hubungan dua variabel mengikuti garis lurus (linear). Analisis data untuk menguji hipotesis penelitian ini menggunakan teknik Pearson product moment. Hasil analisis menunjukkan koefisien korelasi sebesar koefisien $\mathrm{r}=$ $0,649, \mathrm{p}=0,000<0,01$ dan $\mathrm{r}_{\text {tabel }}=0,205$. Hal ini menunjukkan bahwa hipotesis penelitian diterima yaitu ada hubungan yang positif antara asertivitas dengan penyesuaian perkawinan pada dewasa awal di Aceh Tengah.

\section{Analisis Variabel Per karakteristik}

Analisis korelasi per karakteristik dilakukan untuk melihat karakteristik asertivitas yang berhubungan dengan penyesuaian perkawinan. Karakteristik asertivitas yang paling berkorelasi dengan variabel penyesuaian perkawinan adalah individu yang memiliki orientasi aktif; mampu bertanggung jawab dengan keadaan maupun situasi, dan mencari pengalaman baru dengan nilai korelasi $r=0,641$ dengan nilai signifikansi $\mathrm{p}=0.001<0.05$.

Tabel 2. Data Demografi Subjek Penelitian

\begin{tabular}{|c|c|c|c|c|}
\hline \multirow{2}{*}{ Kategori } & \multicolumn{2}{|c|}{ Jenis Kelamin } & \multirow{2}{*}{ Jumlah } & \multirow{2}{*}{$\%$} \\
\hline & Perempuan & Laki-laki & & \\
\hline \multicolumn{5}{|l|}{ Usia } \\
\hline $20-25$ tahun & 26 & 4 & 30 & $33,3 \%$ \\
\hline $26-30$ tahun & 22 & 24 & 46 & $51,1 \%$ \\
\hline $31-35$ tahun & 4 & 10 & 14 & $15,6 \%$ \\
\hline \multicolumn{5}{|c|}{ Usia Perkawinan } \\
\hline $0-6$ bulan & 6 & 5 & 11 & $12,2 \%$ \\
\hline $7-12$ bulan & 18 & 10 & 28 & $31,1 \%$ \\
\hline $13-18$ bulan & 12 & 9 & 21 & $23,4 \%$ \\
\hline $19-24$ bulan & 16 & 14 & 30 & $33,3 \%$ \\
\hline
\end{tabular}

Tabel 3. Deskripsi Hasil Data Penelitian

\begin{tabular}{lcccccccc}
\hline \multirow{2}{*}{ Variabel } & \multicolumn{3}{c}{ Data Hipotetik } & \multicolumn{4}{c}{ Data Empirik } \\
\cline { 2 - 9 } & Xmaks & Xmin & Mean & SD & Xmaks & Xmin & Mean & SD \\
\hline Asertivitas & 64 & 16 & 40 & 8 & 61 & 32 & 47,73 & 5,623 \\
Penyesuaian Perkawinan & 80 & 20 & 50 & 10 & 80 & 48 & 63,27 & 6,127 \\
\hline
\end{tabular}


Tabel 4. Kategorisasi Asertivitas dan Penyesuaian Perkawinan Pada Dewasa Awal di Aceh Tengah

\begin{tabular}{clccc}
\hline Variabel & Rumus Norma Kategori & Kategori & Jumlah & Persentase \\
\hline Asertivitas & $\mathrm{X}<32$ & Rendah & 0 & 0 \\
& $32 \leq \mathrm{X}<48$ & Sedang & 45 & $50 \%$ \\
& $48 \leq \mathrm{X}$ & Tinggi & 45 & $50 \%$ \\
\hline Penyesuaian Perkawinan & $\mathrm{X}<40$ & Rendah & 0 & 0 \\
& $40 \leq \mathrm{X}<60$ & Sedang & 24 & $26,7 \%$ \\
& $60 \leq \mathrm{X}$ & Tinggi & 66 & $73,3 \%$ \\
\hline
\end{tabular}

Pengujian hipotesis yang dilakukan dalam penelitian ini menunjukkan bahwa terdapat hubungan positif dan signifikan antara asertivitas dengan penyesuaian perkawinan pada dewasa awal di Aceh Tengah. Hasil penelitian ini sejalan dengan penelitian yang dilakukan oleh Pudjiastuti dan Santi (2012) menyatakan bahwa individu yang memiliki tingkat asertivitas rendah akan berpengaruh pada penyesuaian perkawinan sehingga individu tersebut memiliki penyesuaian perkawinan yang cenderung buruk. Selanjutnya Widjaja dan Wulan (dalam Marini \& Andriani, 2005) menyatakan asertivitas menimbulkan hubungan interpersonal yang memuaskan karena memungkinkan individu untuk mengemukakan apa yang diinginkan secara langsung sehingga menimbulkan rasa senang dalam diri dan orang lain. Dengan berperilaku asertif individu dapat mangurangi konflik ataupun stres.

Ditambahkan oleh Chen (dalam Amat \& Mahmud, 2008) yang mengatakan individu yang asertif akan lebih mudah dalam menyesuaikan diri dengan lingkungan sekitarnya dan akan lebih mudah berinteraksi dalam situasi sosial. Hasil penelitian Noller (1982) menemukan bahwa istri yang memiliki penyesuaian perkawinan yang buruk menginginkan suaminya untuk mengekspresikan emosinya dengan lebih jelas, memberi lebih banyak perhatian dan apresiasi pada istri, dan lebih banyak berkomunikasi.
Karakteristik asertivitas yang paling memberikan kontribusi terhadap penyesuaian perkawinan yaitu Individu yang memiliki orientasi aktif; mampu bertanggung jawab dengan keadaan maupun situasi, dan mencari pengalaman baru. Karakteristik tersebut memiliki nilai korelasi 0,641 terhadap penyesuaian perkawinan. Hal ini sejalan dengan penelitian yang dilakukan oleh Wulandari (2009) mengatakan bahwa individu yang memiliki orientasi aktif yaitu individu yang memiliki motivasi menikah yang didasari dengan keinginan untuk meneruskan garis keturunan, perasaan saling mencintai, dan untuk memenuhi kewajiban agama, maka baik suami maupun istri akan berusaha untuk saling mengerti, menghargai, toleransi, bertanggung jawab, dan bersedia berkorban untuk pasangannya agar tercapai hubungan yang harmonis dan perkawinan akan langgeng.

Hasil dari penelitian ini juga memperlihatkan bahwa faktor lain, selain asertivitas yang memengaruhi penyesuaian perkawinan yang dapat dilihat dari koefesien korelasi sebesar 0,649. Berdasarkan penelitian yang dilakukan oleh Anissa dan Handayani (2012) hal yang berpengaruh dalam penyesuaian perkawinan adalah kematangan emosi, dimana individu dapat mengontrol atau mengendalikan emosi sesuai dengan taraf perkembangan emosinya, serta dapat berpikir secara matang, baik dan objektif. Walgito (2009). Individu 
yang memiliki kematangan emosi akan memiliki kemampuan berpikir secara baik sehingga dapat menempatkan persoalan secara objektif.

Penelitian yang dilakukan oleh Laurenceau dan Barrett (2005) menunjukkan bahwa penyesuaian perkawinan juga dipengaruhi oleh keterbukaan diri dan keterbukaan pasangan respon yang diberikan istri atau suami terhadap apapun yang disampaikan oleh pasangannya akan memberikan dampak terhadap kesediaan pasangan tersebut untuk lebih terbuka terhadap pasangannya. Sejalan dengan penelitian yang dilakukan oleh Rachmawati dan Mastuti (2013) individu yang mampu melakukan penyesuaian perkawinan yang baik memiliki tingkat kepuasan perkawinan yang tinggi, karakteristik mencapai kepuasan perkawinan salah satunya adalah dengan komunikasi yang terbuka, hal ini sangat dibutuhkan dalam penyesuaian perkawinan.

Penelitian ini menunjukkan bahwa 50\% sampel yang menikah di Aceh Tengah tergolong memiliki asertivitas tinggi. Hal ini berarti dewasa awal yang menikah di Aceh Tengah mampu berperilaku asertif. Ada beberapa hal yang memengaruhi perilaku asertif seperti penelitian yang dilakukan oleh Simbolon (2008) memperlihatkan bahwa asertivitas memiliki hubungan positif dengan harga diri. Hasil ini memperlihatkan bahwa individu yang memiliki harga diri yang tinggi dapat mengekspresikan dirinya dengan baik. Individu dengan harga diri tinggi menyukai tugas baru dan menantang, dan dapat mengontrol dirinya. Hal ini dapat dikatakan sejalan dengan karakteritik individu yang asertif menurut Myers dan Myers (1992) yaitu individu dapat mengekspresikan dirinya dan mengungkapkan perasaannya serta mencari pengalaman baru.
(1983) terdapat 6 faktor yang memengaruhi perkembangan perilaku asertif salah satunya jenis kelamin yang menyatakan wanita pada umumnya lebih sulit berperilaku asertif seperti mengungkapkan perasaan dan pikiran dibandingkan dengan laki-laki. Berdasarkan data demografis dapat dilihat bahwa mayoritas sampel penelitian ini adalah perempuan yang berjumlah 52 dari 90 sampel dengan $88 \%$ tingkat asertivitas pada sampel penelitian berada dalam kategori tinggi. Hal ini menunjukkan bahwa sampel penelitian yaitu perempuan juga menyumbang nilai asertivitas yang tinggi. Hasil penelitian ini menunjukkan perbedaan dengan teori yang disebutkan oleh Rathus dan Nevid (1983).

Selain itu penelitian yang dilakukan oleh Amat dan Mahmud (2009) menyatakan bahwa individu yang asertif akan lebih mudah dalam penyesuaian diri terutama dalam berhubungan dengan orang lain yang berdampak pada kepuasan hidup, dan mampu menjalin hubungan yang baik dengan orang lain. Hergina (2012) mengatakan individu yang memiliki konsep diri yang tinggi dapat mendorong individu untuk berperilaku asertif, individu yang memiliki konsep diri yang tinggi tidak merasa minder ketika beradaptasi dengan lingkungan baru maupun sekitarnya, dan dimungkinkan akan meningkatkan perilaku asertif, karena memiliki intensitas yang tinggi dalam melakukan komunikasi dengan orang lain.

Penelitian ini menunjukkan hasil $73,3 \%$ sampel yang menikah di Aceh Tengah tergolong memiliki penyesuaian perkawinan yang baik. Hal ini didukung dengan budaya suku Gayo, sebagai suku mayoritas di Aceh Tengah yang menganut sistem perkawinan eksogami (perkawinan 
berlainan suku). Bagi masyarakat Gayo sistem pernikahan endogami (pernikahan satu suku dan ras) menjadi larangan atau pantangan karena sesama suku Gayo masih dianggap memiliki ikatan persaudaraan atau ikatan darah (Selian, 2007). Hasil ini diperkuat oleh penelitian Mulyono (2012) yang menemukan bahwa invidu yang menikah dengan latar budaya yang berbeda dapat melakukan penyesuaian perkawinan. Selain itu terdapat beberapa faktor yang memengaruhi penyesuaian perkawinan seperti karakteristik pribadi, usia saat menikah, pendidikan, jumlah anak, pendapatan, dan penyesuaian keluarga. Berdasarkan data demografi penelitian, diketahui sekitar $65,5 \%$ sampel tinggal bersama pasangan, sedangkan $34,5 \%$ sampel lainnya tinggal bersama orangtua atau mertua dengan $73,3 \%$ penyesuaian perkawinan berada dalam kategori baik. Hal ini terjadi karena mayoritas sampel penelitian memiliki asertivitas yang tinggi. Selain itu mayoritas sampel pada penelitian ini adalah perempuan. Penelitian yang dilakukan oleh Anissa dan Handayani (2012) didapati bahwa sebagian besar istri yang tinggal bersama mertua dapat melakukan proses penyesuaian diri yang baik dengan keluarga suami. Istri dapat berinteraksi secara baik untuk mendapatkan hubungan yang serasi dengan anggota keluarga suami yang ditunjukkan dengan kemampuan istri berkomunikasi yang baik dengan anggota keluarga suami, istri mampu memahami kondisi keluarga suami, istri memiliki pengendalian diri yang baik, istri dapat bertindak sesuai norma yang dianut keluarga suami.

Peneliti menyadari keterbatasan dari penelitian ini yaitu subjek yang digunakan dalam penelitian ini hanya 90 orang dari keseluruhan dewasa awal yang menikah di Aceh Tengah dengan jumlah sampel tersebut penelitian ini tidak representatif atau tidak mewakili sejumlah populasi yang ada sehingga hasil penelitian ini tidak bisa digeneralisasikan ke dewasa awal di Aceh Tengah. Selanjutnya untuk memperdalam hasil penelitian, kedua variabel akan lebih kaya bila diteliti dengan metode kualitatif.

\section{SIMPULAN}

Hasil penelitian ini menunjukkan bahwa ada hubungan antara asertivitas dengan penyesuaian perkawinan pada dewasa awal di Aceh Tengah. Penelitian ini juga memperlihatkan bahwa asertivitas berada dalam kategori tinggi dan penyesuaian perkawinan dewasa awal di Aceh Tengah berada dalam kategori baik. Hal ini menunjukkan semakin tinggi tingkat asertivitas dewasa awal maka semakin baik penyesuian perkawinan dewasa awal.

\section{SARAN}

Berdasarkan hasil penelitian ini maka terdapat beberapa saran yang peneliti berikan, yaitu:

1. Kepada Sampel Penelitian

Pada dewasa awal yang menikah di Aceh Tengah agar mempertahankan dan meningkatkan kemampuan dalam berperilaku asertif dengan mampu mengatakan apa yang dirasakan dan diinginkan pada pasangan agar penyesuaian dalam perkawinan berjalan dengan lancar dan masalah dalam perkwinan dapat diselesaikan.

2. Kepada Peneliti Selanjutnya

Bagi peneliti selanjutnya yang ingin meneliti asertivitas agar terus mencari informasi terkini atau teori yang berkembang mengenai variabel tersebut. Selanjutnya untuk penyesuaian perkawinan diharapkan agar dapat mengkaji variabelvariabel lain sebagai faktor yang memengaruhi penyesuaian 
perkawinan seperti kematangan emosi, konsep diri, persepsi saat menikah. Untuk memperdalam hasil penelitian dapat dilakukan dengan metode kualitatif.

Saran lainnya bagi peneliti yang ingin melakukan penelitian dewasa awal yang menikah sebaiknya mempertimbangkan waktu pengambilan data yang tepat. Berdasarkan pengalaman peneliti yang dilakukan proses penelitian mendatangi rumah pada saat hari aktif bekerja didapati kurang efektif untuk melakukan pengumpulan data. Jadi, sebaiknya pengambilan data penelitian dilakukan pada saat hari libur.

\section{DAFTAR PUSTAKA}

Anjani, C. \& Suryanto. (2006). Pola penyesuaian perkawinan pada periode awal. Insan, 8 (3), 198-210.

Anissa, N. \& Handayani, A. (2012). Hubungan antara konsep diri dan kematangan emosi dengan penyesuaian diri istri yang tinggal bersama keluarga suami. Jurnal Psikologi Pitutur, 1 (1), 57-67.

Amat, S. \& Mahmud, Z (2009). Hubungan antara ketegasan diri dan kepuasan hidup dalam kalangan pelajar institusi pengajian tinggi. Jurnal Pendidikan Malaysia, 34 (2), 49 65.

Atwater, E. \& Duffy, K. G. (2009) Psychology for living: adjustment, growth, and behavior today. Six editions. New Jersey: Prertice-Hall.

Azwar, S. (2012). Penyusunan Skala Psikologi Edisi 2. Yogyakarta: Pustaka Pelajar.

Dariyo, A. (2004). Psikologi perkembangan dewasa muda. Jakarta: PT. Gramedia Pustaka Utama.

Degenova, \& Kay., M. (2005). Intimate relationships, Marriage and Families. New York: Mc Graw-Hill Companies.
Devito, J. P. (2009). The interpersonal communication book. New York: Haper Collins College Publihers.

Duvall, E. M. (1977). Mariage and the family development. New York: Philadelphia B lipincott company.

Hergina, I. (2012). Hubungan antara konsep diri dengan perilaku Asertif pada siswa MAN Wonokromo Bantul Yogyakarta. Jurnal EMPATHY, 1 (1), 273-283.

Hurlock, E.B.( 2009). Psikologi perkembangan: suatu pendekatan sepanjang rentang kehidupan. Jakarta: Erlangga.

Kertamuda, F. E. (2009). Konseling perkawinan untuk keluarga Indonesia. Jakarta: Salemba Humanika.

Laurenceau, J.P. \& Barrett. (2005). The interpersonal process model of intimacy in marriage: a daily-dairy and multilevel modeling approach. Journal of Family Psychology, 19(2), 314-323.

Lee, \& Ok. (2002). Family of Origin Influences on Anxiety, Open Communication, and Relationship Satisfaction. A Test of Bowenian theory of Anxiety as Mediator in the Intergenerational Transmission. Journal of Korean Home Economics AssociationEnglish, 3(1), 111-126.

Mahkamah Syar'iyah Aceh. Informasi data perceraian di Aceh tahun 20092013.

Marini, L., \& Andriani, E. (2005). Perbedaan asertivitas remaja ditinjau dari pola asuh orang tua. Psikologia, 1(2). Hal 46-53.

Mulyono, A. S. (2012). Faktor-faktor yang memengaruhi penyesuaian perkawinan pada istri beretnis Cina yang mempunyai suami beretnis Jawa. Skripsi. Fakultas Psikologi Universitas Katolik Soegijapranata Semarang.

Myers, G. E., \& Myers, M. T. (1992). Thedynamics of human communication. New York: McGraw Hill Book Company.

Noller, P. (1982). Couple communication and marital satisfaction. Journal of Family Studies, 03(02), 069-075. 
Prabowo, M. R. (2006). penyesuaian perkawinan pada pasangan yang berlatar belakang etnis Batak dan etnis Jawa. Skripsi. Diakses pada tanggal 4 september 2013, melalui http://www.gunadarma.ac.id/library/ articles/graduate/psychology/2006/a rticles_10500255.pdf

Pudjiastuti, E. \& Santi, M. (2012). Hubungan antara asertivitas dengan penyesuaian perkawinan pasangan suami istri dalam usia perkawinan 1-5 tahun di kecamatan coblong bandung.Jurnal Sosial,3(1), 9-16.

Rachmawati, D. \& Mastuti, E. (2013). Perbedaan tingkat kepuasan perkawinan ditinjau dari tingkat penyesuaian perkawinan pada istri brigif 1 marinir TNI - AL yang menjalani Long distance marriage. Jurnal Psikologi Pendidikan dan Perkembangan, 02(01), 1-8.

Rathus, S.A. \& Nevid, J.S. (1983). Adjustment and growth: The challenges of life (2nd ed). New York: CBS College Publising.
Rini, S. I. R. (2009). Hubungan antara keterbukaan dengan penyesuaian perkawinan pada pasangan suami istri yang tinggal terpisah. Jurnal PSYCHO IDEA. Vol 7. No 2. Hal 113.

Selian, R.S. (2007). Analisis semiotik: upacara perkawinan "ngerje" kajian estetika tradisional suku Gayo di dataran tinggi gayo Kabupaten Aceh Tengah. Tesis. Progran Studi Pendidikan Seni Pascasarjana Univesitas Negeri Semarang.

Simbolon, S. H. (2008). Hubungan harga diri dengan asertifitas pada remaja. Skripsi. Fakultas Psikologi Sumatera Utara Medan.

Walgito, B. (2009). Bimbingan dan konseling perkawinan. Yogyakarta: Andi.

Wulandari, I. (2009). Penyesuaian perkawinan pada pasangan suami istri dewasa muda ditinjau dari persepsi terhadap perkawinan dan motivasi menikah. Skripsi. Fakultas Psikologi Universitas Katolik Soegijapranata Semarang. 